\title{
NOTE
}

\section{ORGANIZATIONAL CYNICISM}

\author{
JAMES W. DEAN, JR. \\ University of North Carolina at Chapel Hill \\ PAMELA BRANDES \\ Southern Connecticut State University \\ RAVI DHARWADKAR \\ University of Cincinnati
}

\begin{abstract}
What is the nature of the extremely negative attitudes expressed by so many employees toward their organizations? To respond to this question, we introduce the concept of organizational cynicism. We review the literature from several disciplines on this concept and suggest that organizational cynicism is an attitude composed of beliefs, affect, and behavioral tendencies toward an organization. Following our review and conceptualization, we derive implications of this concept and propose $\alpha$ research agenda for organizational cynicism.
\end{abstract}

Cynicism is everywhere-widespread among organization members in the United States (Kanter \& Mirvis, 1989), Europe, and Asia (Kouzes \& Posner, 1993). Organizational change and quality improvement efforts particularly seem to engender cynicism (Shapiro, 1996). For example, Cunniff notes that employees are increasingly cynical about the "constant parade of initiatives that come with the usual promise of imminent improvement" (1993: 4). Employees in one company circulated clandestine copies of their firm's "adaptation" of the Deming Principles, which included "Humor all employees in phony efforts to include them in process improvement methodologies.... Provide slogans, meaningless exhortations [and] numerical goals.... Drive in fear by discouraging communication and by instituting a policy of Continuous Layoff."

These observations are echoed in our own experience by the reaction of part-time MBA students to the topic of "teamwork" (cross-functional collaboration) in organizations. These students

We thank Lynne Andersson, Harold Angle, Daniel Brass, Thomas Debbink, Dennis Gioia, Katherine Klein, and Anand Narasimhan for their helpful comments on an earlier draft of this article. This research was supported by a grant from the University of Cincinnati Faculty Summer Research Fellowship. could see the benefits of teamwork in theory but perceived it, in practice, as merely a slogan used by their organizations to appear progressive, without changing anything about how work actually gets done (cf., Aktouf, 1992). A young woman in this class was so appalled by her organization that she thought she must be part of "some huge experiment on unmotivating employees." Another young man had been invited to lunch with his coworkers by the management of his organization; he accepted the invitation but worried that management had only made the offer "to keep us off guard." Even the popularity of the comic strip "Dilbert," about an engineer whose organization plumbs the depths of unscrupulousness, suggests that many people perceive their organizations in these terms. In fact, much of the material for the strip actually is sent to the cartoonist via e-mail by frustrated employees (Greilsamer, 1995).

This article is about organization members' cynicism toward their organizations-an attitude that appears to be both widespread and ignored by organizational research. We address one major question: how should organizational cynicism be conceptualized? We organize this article as follows. First, we discuss the origin of the concept of cynicism and briefly review the literature that has begun to appear on this topic. We then propose a conceptualization of cynicism in organizations and discuss a number of 
issues related to this conceptualization. Next, we compare organizational cynicism to other existing organizational constructs. Finally, we propose a research agenda for organizational cynicism.

\section{CONCEPTIONS OF CYNICISM}

\section{Origins of the Concept of Cynicism}

Cynicism as a school of thought and a way of life originated in ancient Greece. The term itself may have come from the Greek word for dog (kyon) or from Cynosarges, a town near Athens where the Cynics had their school. The first Cynic was Antisthenes, originally a follower of Socrates, but he has been overshadowed in history by his student Diogenes of Sinope, who became famous for carrying a lamp in daylight to help him find one honest man. Believing that the individual, and not the organization, was the natural unit of human life, Cynics felt that even cherished institutions, such as religion and government, were unnatural and unnecessaryworthy only of scorn (Fuller, 1931). Cynics were openly contemptuous of such institutions and were known for using dramatic and obscene displays to draw people into conversations, in which they could proclaim their views (Mack, 1993). Humor was the favorite weapon of the Cynics, the privileged and powerful their favorite target.

Cynicism was, from the beginning, as much a lifestyle as a philosophy (More, 1923). Cynics believed that men's conventions were unnatural and should be avoided, as much as possible, in the name of the independence and self-sufficiency that characterize a good life. Rejecting societal standards, Cynics wore rough clothing and drank out of their hands so as not to need a cup. Diogenes is even said to have lived in a tub instead of a house. In short, the original Cynics held society's institutions in very low regard and expressed contempt for them in both words and actions.

Over the centuries the terms "cynic," "cynical," and "cynicism" have taken their place in our language, with meanings that are loosely derived from the tenets of Cynicism. The Oxford English Dictionary (1989) defines a cynic as "one who shows a disposition to disbelieve in the sincerity or goodness of human motives and actions, and is wont to express this by sneers and sarcasms; a sneering fault-finder." In the next section we discuss how various researchers have interpreted the idea of cynicism.

\section{Conceptualizations of Cynicism in Research}

Five major conceptualizations of cynicism seem to characterize the literature thus far. A useful review of these should compare and contrast existing conceptualizations in order to demonstrate areas of distinction, as well as areas of overlap between concepts. One method for comparing conceptualizations is facet design (Guttman, 1954; Schwab, 1980; Shapira \& Zevulun, 1979). While this technique can be used for hypothesis development and testing on more mature concepts, our purpose in applying this technique will be more "taxonomic," in order to contrast different approaches to cynicism.

Extant conceptualizations of cynicism (see Table 1) can be compared in terms of their related concepts, foci, definitions, epistemic correlations (the relationship between the conceptualization and the measurement of a construct; Northrop, 1959), overlaps with/preclusion of other cynicism forms, internal reliability, relative importance of determinants (e.g., person versus situational characteristics), and the assumed permanence and means of influencing the construct (Morrow, 1983). In addition to these categories, we include in Table 1 yet another means of comparison: theoretical predecessors. Because of space considerations, we mean the citations included to be illustrative rather than exhaustive.

Personality approaches. Researchers using personality-based approaches to cynicism generally discuss cynicism as an overall outlook on human nature. Studies in this tradition are based on Cook and Medley's (1954) hostility scale-a subset of items from the Minnesota Multiphasic Personality Inventory (MMPI). Graham (1993) suggests that individuals who score high on MMPI cynicism scales see others as selfish and uncaring, question the motives of others, and are guarded and untrusting in relationships. Scholars undertaking current discussions of the hostility concept within psychology and medicine interpret Cook and Medley's work as representing "cynical hostility," which includes distrust in others but not overt expressions of aggression (e.g., Barefoot, Dodge, Peterson, Dahlstrom, \& Williams, 1989; Costa, 


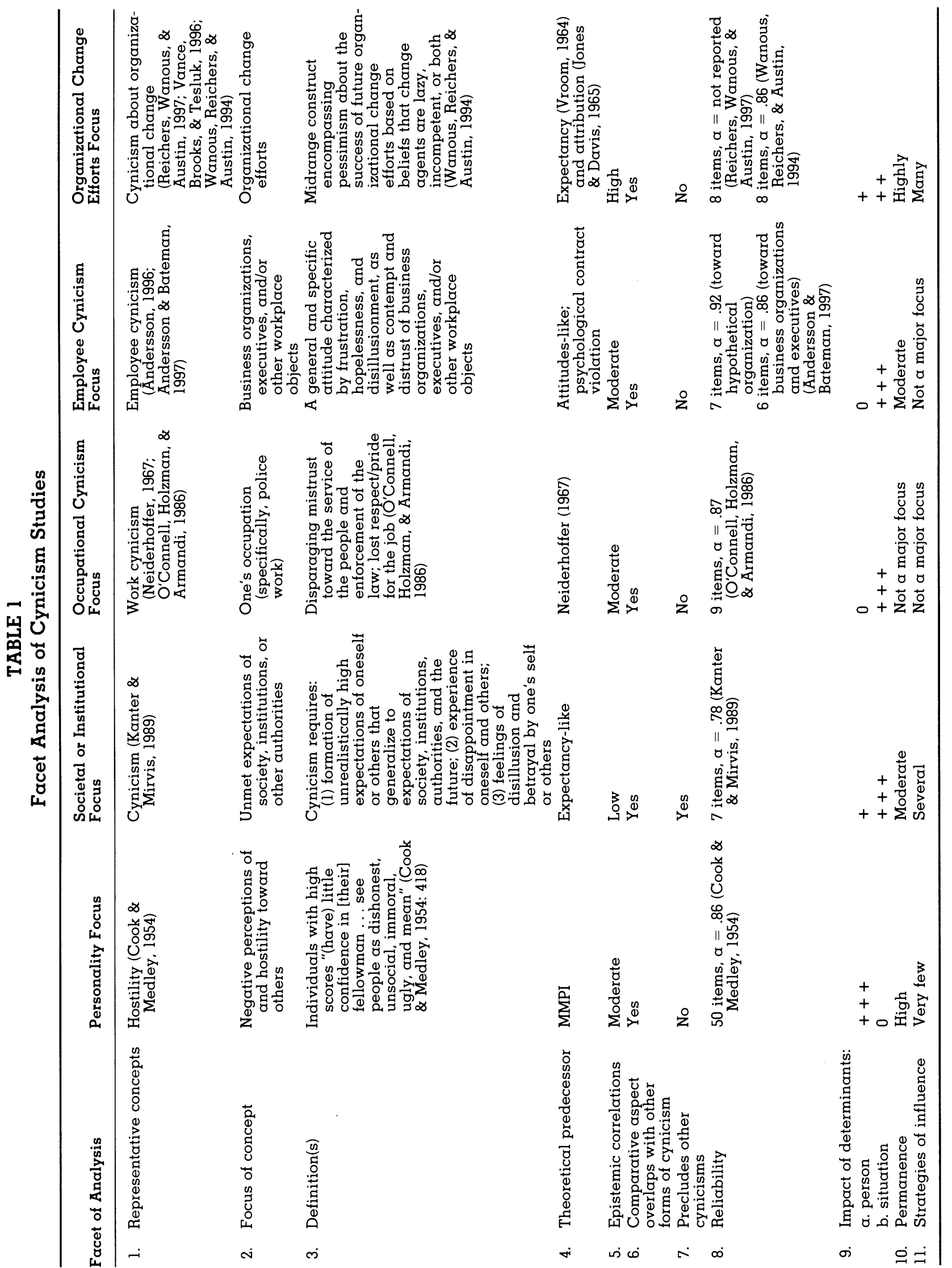


Zonderman, McCrae, \& Williams, 1986; Greenglass \& Julkunen, 1989). The Cook and Medley hostility scale reflects more individuals' impressions of themselves (e.g., "I have often met people who were supposed to be expert who were no better than I") and less their view of people in general, which has been the focus of Wrightsman's (1974) Philosophies of Human Nature Scale (cynicism subscale). As a result of a traitbased approach, research within this tradition assumes that little can be done to change one's degree of cynicism.

Societal/institutional focus. According to Kanter and Mirvis (1989), Americans' cynical outlook on life has resulted from fluctuating fortunes in the American social and political milieus in the twentieth century. Other contributors to cynicism include exploitation of workers during the early stages of industrialization and the failed promise of modern organizations to improve life at work. Although Kanter and Mirvis discuss cynicism as including disillusionment with society, self, institutions, or others, their operationalization deals with people's impressions of others in general. In other words, because of the nature of their operationalization, there is some overlap between their conception of cynicism and the personality approach to cynicism. Kanter and Mirvis's analysis indicates that cynicism has become an inherent characteristic of many Americans, suggesting that 43 percent of the workforce is cynical. However, their description of the evolution of cynicism as $\alpha$ response to the failed promises of society, as well as their attention to demographic variables (e.g., gender, race, education, and income), suggests a situational component; counter to the personality approach, they propose that cynicism levels can be managed, and they offer several ways that organizations can create work cultures to counter it.

Occupational cynicism focus. In his studies of urban policing, Niederhoffer (1967) noted the development of "police cynicism," which he describes as "a byproduct of anomie in the social structure" (1967: 95) of policing stemming from the interaction of role ambiguities and conflicting pressures regarding professionalization of police work. O'Connell, Holzman, and Armandi (1986) found that officers had two targets for their cynicism: (1) the organization (organizational cynicism) and (2) the service of the people and of the law (work cynicism). O'Connell et al. (1986) suggest that high and low levels of work and organizational cynicism combine to create four different adaptation styles. Although correlated, the relationship between work and organizational cynicism was not so high as to suggest that they were the same construct. Work cynicism was higher for those officers who (1) had less complex work details, (2) had rotating shifts, (3) had nonpreferred details, and (4) worked in the precinct.

Employee cynicism focus. Andersson (1996) and Andersson and Bateman (1997) suggest three potential targets for cynicism: (1) business organizations in general, (2) corporate executives, and (3) "other" workplace objects. Employee cynics within this approach are noteworthy for their negative feelings, such as contempt, frustration, and hopelessness toward these targets. Researchers see employee cynicism as a result of violations of psychological contracts and describe this cynicism within the realm of attitudes. Using a scenario-based methodology, Andersson and Bateman found that employee cynicism toward a hypothetical organization was related to high levels of executive compensation, poor organizational performance, and harsh organizational layoffs. Additionally, cynicism toward three targets was negatively related to self-reported intent to perform organizational citizenship behaviors.

Organizational change focus. Reichers, Wanous, and Austin (1997) suggest that organizational change efforts are the appropriate target of cynicism. Specifically, they describe cynicism as an attitude consisting of the futility of change along with negative attributions of change facilitators. Similarly, Vance, Brooks, and Tesluk suggest that organizational cynicism is a "learned belief that fixable problems at work will not be resolved due to factors beyond the individual's control" (1996: 1), but unlike Reichers et al., they suggest that cynics believe that things could be better. Cynicism about organizational change (CAOC) has a specific target (organizational change efforts) but does not preclude other forms of cynicism. In fact, these authors suggest that negative affect (a personality variable) is positively related to CAOC. While acknowledging the impact of personality variables, Reichers et al. (1997) emphasize the strength of situational variables: being an hourly employee, perceiving less participation in decisions, and perceiving poor information flows and follow-ups all are related to CAOC. 
Furthermore, Reichers et al. offer several recommendations for managing cynicism, which include efforts at involving people in decisions that affect them, enhancing the credibility of management, and keeping surprising changes to a minimum.

In summary, scholars have observed cynicism through various theoretical lenses and have offered several targets for cynicism, including other people in general, societal institutions, one's occupation, top managers, and organizational change efforts.

\section{A NEW CONCEPTUALIZATION OF ORGANIZATIONAL CYNICISM}

Our task now turns to conceptualizing organizational cynicism in a way that captures the generally understood meaning of this term and provides a solid foundation for operationalization and measurement. We will also distinguish organizational cynicism from constructs frequently used in organizational studies. Both of these tasks are essential to the development of constructs within organizational behavior. We hope to add to existing knowledge by creating a unique conceptualization that we believe captures the essence of the construct while defining it in precise terms.

In order to put organizational cynicism on solid conceptual and theoretical footing, we have conceptualized it as an attitude, which is "a disposition to respond favorably or unfavorably to an object, person, institution, or event" (Ajzen, 1994: 114). Psychologists suggest that evaluation is the core of attitudes (Eagly \& Chaiken, 1993). We define organizational cynicism as follows:

\begin{abstract}
Organizational cynicism is a negative attitude toward one's employing organization, comprising three dimensions: (1) a belief that the organization lacks integrity; (2) negative affect toward the organization; and (3) tendencies to disparaging and critical behaviors toward the organization that are consistent with these beliefs and affect.
\end{abstract}

Our conception of cynicism, thus, is multidimensional, corresponding to the three componentsbeliefs, affect, and behavioral tendencies-that have long characterized attitude theory (Eagly \&
Chaiken, 1993; Hilgard, 1980; Smith, 1947). All three components vary on an evaluative continuum, from positive to negative (Allport, 1935; Breckler, 1984). Thus, we do not focus on cynicism as a personality trait-a characteristic of people who are cynical about everything-but rather as a state-an aspect of people that may change over time and that is directed at a specific target: their organization (cf., Hart, 1997).

One assumption of our definition is that an organization can be the object of an attitude. Ajzen's (1994) definition of attitudes, which includes "institutions" as potential attitude objects, makes clear that this is consistent with attitude theory. There is also a substantial precedent for this assumption in the literature on organizational commitment (Porter, Steers, Mowday, \& Boulian, 1974) and on perceived organizational identity (e.g., Dutton, Dukerich, \& Harquail, 1994). Bateman, Sakano, and Fujita (1992) also have demonstrated that people hold attitudes about specific organizations, whereas Levinson (1965) discusses the broader tendencies of individuals to personify organizations.

A further assumption is that people can form an attitude about their employing organization based on the behavior of the people in the organization. Although occasional perceptions that organizational practices lack integrity may be attributed to the specific individuals involved, perceptions that such behavior is widespread and enduring in the organization are more likely to be attributed to organizational characteristics (Dutton et al., 1994). Moreover, some of the perceptions upon which cynical attitudes are based-concerning policies, processes, or other systemic elements of the organization-may be difficult to relate to specific individuals.

\section{Beliefs}

The first dimension of organizational cynicism is the belief that the organization lacks integrity. Returning to the Oxford English Dictionary, we find integrity defined as "soundness of moral principle; the character of uncorrupted virtue, especially in relation to truth and fair dealing; uprightness, honesty, sincerity." Upon relating this back to the dictionary definition of cynicism ("a disposition to disbelieve in the sincerity or goodness of human motives and actions"), we see that a concise statement of cyn- 
ical beliefs is that people lack integrity (see Becker, 1998, for an alternative conceptualization of integrity).

Thus, organizational cynics believe that the practices of their organizations betray a lack of such principles as fairness, honesty, and sincerity. These cynics may believe that, in their organization, such principles are often sacrificed to expediency and that unscrupulous behavior is the norm. They may also believe that choices of organizational direction are based on selfinterest (Goldner, Ritti, \& Ference, 1977) and that people are inconsistent and unreliable in their behavior. Cynics often believe there are hidden motives for actions; thus, they expect to see deception rather than candor and are unlikely to accept at face value the official rationale for organizational decisions.

\section{Affect}

Attitudes are composed of affect-that is, emotional reactions to the attitude object-as well as beliefs (Eagly \& Chaiken, 1993). This implies that cynicism is felt as well as thoughtexperienced through emotion as well as cognition. Cynicism is not a dispassionate judgment about the organization; it can include powerful emotional reactions. In conceptualizing this affective component of cynical attitudes, we rely primarily upon the work of Izard (1977), who identifies nine basic emotions, each of which is described in both a mild and strong form: (1) interest-excitement, (2) enjoyment-joy, (3) surprise-startle, (4) distress-anguish, (5) anger-rage, (6) disgust-revulsion, (7) contempt-scorn, (8) fearterror, and (9) shame-humiliation.

The affective dimension of organizational cynicism comprises several of these emotions. Cynics may, for example, feel contempt for and anger toward their organization. They may also experience distress, disgust, and even shame when they think about their organization. Thus, cynicism is associated with a variety of negative emotions. Ironically, however, cynics may also experience a secret enjoyment of their superiority to the organization, which they have judged by their standards and found wanting. Therefore, we see organizational cynics as not only holding certain beliefs about their organizations but also as experiencing a related set of emotions.

\section{Behavior}

The final dimension of organizational cynicism is tendencies toward negative, and often disparaging, behavior. The general thrust of the literature indicates that cynical attitudes comprise tendencies toward certain types of behavior, rather than specific behaviors per se (e.g., Ajzen, 1994). Echoing the ancient Cynics, the most obvious behavioral tendency for those with cynical attitudes is the expression of strong criticisms of the organization. This may take a variety of forms, the most direct of which is explicit statements about the lack of honesty, sincerity, and so on, on the part of the organization. Employees also may use humor, especially sarcastic humor, to express cynical attitudes. Expressing interpretations of organizational events that assume a lack of integrity on the part of the organization may be a behavioral tendency that characterizes organizational cynics as well-for example, the employee who says that the only reason the company is interested in environmental issues is to generate good public relations. Organizational cynics may tend to make pessimistic predictions about the future course of action in the organization. For example, they may predict that a quality initiative will be abandoned as soon as it begins to be costly. Finally, tendencies toward certain types of nonverbal behavior may be used to convey cynical attitudes. This includes "knowing" looks and rolling eyes, as well as the smirks and sneers by which cynics (and Cynics) have long been known.

In summary, we have conceptualized organizational cynicism as an attitude composed of beliefs, affect, and behavioral tendencies. Thus, we see organizational cynicism as a multidimensional construct: people are considered cynical about their organization to the extent that they hold certain beliefs about the organization's (lack of) integrity, experience certain types of affect toward the organization, and display certain behavioral tendencies toward the organization. We can conceptualize the strength of the attitude of cynicism as a function of the strength of each of the individual dimensions. However, research generally has shown the three components of attitudes to be highly intercorrelated (e.g., Breckler, 1984). Implicit in this discussion is the assumption that organizational cynicism is a continuum: the world is not 
divided into cynics and noncynics, and people have widely varying degrees of cynicism.

\section{ADVANTAGES OF OUR CONCEPTUALIZATION OF ORGANIZATIONAL CYNICISM}

We believe our conceptualization of organizational cynicism provides a number of advantages over existing conceptualizations. Many of these advantages are based on our use of the tripartite attitude framework. First, our conceptualization makes it clear that organizational cynicism is a state-not a trait-which implies both that it is based on specific organizational experiences and that it is likely to change somewhat over time as individuals' experiences change. By relying on an attitudes framework, we have clearly differentiated organizational cynicism from personality- or trait-based cynicism, which focuses on human nature in general. Second, it is not limited to a particular type of work, such as police work; cynicism certainly is observable in a wide range of occupations. Third, our conceptualization rounds out the construct by including affect and behavior, as well as beliefs. Although the cognitive element of organizational cynicism is quite important, the construct would be impoverished without a consideration of its emotional and behavioral dimensions. Finally, by focusing on the organization as the target of cynicism, constructs such as cynicism about organizational change are subsumed into a broader whole, from which, perhaps, they can be derived. If employees see organizations as generally insincere and duplicitous, then it makes sense that organizational changes will not be expected to be seriously undertaken and, therefore, will be expected to fail. However, unlike the societal and occupational variants of cynicism $i$ in which targets include governments, education, religion, or occupations, our approach restricts the target of cynicism to one's employing organization.

\section{CONCEPTUAL ISSUES IN DEFINING ORGANIZATIONAL CYNICISM}

In attempting to conceptualize a new construct, we must address a number of issues in order to explain and justify our definition. The issues we address here include (1) the validity of cynical beliefs, (2) the value of cynicism, (3) the appropriate level of analysis for organizational cynicism, and (4) the distinction between organizational cynicism and other constructs.

\section{The Validity of Cynical Beliefs}

It may well have occurred to some readers that cynics may be right-that is, correct in their evaluations of their organization. Our definition takes no position on the factual basis (or lack thereof) for cynical attitudes. Whatever their real or imagined basis, these attitudes are equally valid to the individuals who hold them. Moreover, it would be virtually impossible to distinguish between "justified" and "unjustified" organizational cynicism because so much of what happens in organizations is open to different interpretations (e.g., Pfeffer, 1981; Weick, 1979). For example, one could argue about whether an organization is being heartless in laying people off or making a principled decision to save as many people as possible. Determining whether cynicism is justified is ultimately a matter of opinion, which would be a very unstable basis for theory. The better approach appears to be to conceive of cynicism simply in terms of attitudes, leaving aside the question of their validity.

\section{The Value of Cynicism}

Cynicism is not a particularly valued attribute in our culture; referring to someone as a cynic generally is not intended as a compliment. Cynics may be depressing to be with, their pessimism may undermine their relationships, and their skepticism about the truth of anything they hear may cause them to miss out on attractive opportunities. However, cynicism can be functional (at least up to a point) for both individuals and organizations. At the individual level, people who invariably believe in others' integrity are likely to be taken advantage of by those who lack it. For the organization, cynics may provide a necessary check on the temptation to place expediency over principle or the temptation to assume that self-interested or underhanded behavior will go undetected. In their particular manner cynics may act as the voice of conscience for the organization, much as the Cynics did for their culture. Thus, we should see organizational cynicism as neither an unalloyed good nor an unalloyed evil for organizations. 


\section{The Appropriate Level of Analysis}

A third issue with which we must deal is the level of analysis for organizational cynicism. The level of organizational cynicism is clearly the individual. By operationalizing organizational cynicism as an attitude, we are targeting an individual's cynicism as the focal construct to be explained. This does not mean that individuals in the same subunit or even organization may not have similarly cynical attitudes. It does mean, however, that we will not assume similarity of attitudes among people at a given level by conceptualizing our construct at any level above that of the individual.

\section{Comparison of Organizational Cynicism with Other Constructs}

In proposing a new construct in the general area of employee attitudes, we must differentiate it from those that already exist in order to avoid the appearance of "old wine in new bottles." Several constructs (organizational commitment, trust, job satisfaction, and alienation) appear to have potential overlaps with organizational cynicism (Table 2).

Organizational commitment. This construct has held a prominent position within organizational studies (e.g., Steers, 1977). The question is, does organizational cynicism simply represent a lack of commitment? When we compare each of organizational commitment's elements to those of organizational cynicism, we identify several differences between the constructs. First, within the cognitive realm, an organizationally cynical employee believes that the practices of his or her employing organization lack integrity, whereas commitment deals with whether employees believe their personal values and goals are similar to the organization's. Second, cynical employees may or may not entertain thoughts of quitting their organization, whereas the behavioral component of commitment includes an employee's intent to stay with the employer. Third, within the affective domain, an organizationally cynical employee is likely to experience such feelings as frustration and contempt toward his or her organization, whereas a noncommitted employee is simply likely to lack pride and attachment to the organization. Our discussion suggests that, although the two constructs may be somewhat negatively related, cynicism clearly is different from and more extreme than a lack of commitment.

Trust. Trust is an old concept that scholars recently have shown a resurgence of interest in (e.g., Bromiley \& Cummings, 1995; Hosmer, 1995; Mayer, Davis, \& Schoorman, 1995). Recent reviews on trust suggest that a truster makes an assessment of the likelihood of another party's willingness to take into account the interests of the parties concerned within a transaction. We should note that trust itself is the willingness to be vulnerable to the actions of others and should not be confused with trusting behavior or actually putting oneself at risk by the actions of others (Mayer et al., 1995). Trust does not include affect, although we may experience negative or positive affect based on the outcomes of a transaction.

Trust and organizational cynicism differ in several dimensions. First, a lack of trust may be based on a lack of experience-that is, when a person has not had enough experience to be confident in trusting the other party. Cynicism, in contrast, almost certainly is based on experience. Although one can easily imagine a lack of trust from one person toward another party based on a lack of experience to justify such trust, it is unlikely that someone in similar circumstances would be cynical about the other party (e.g., proclaim his/her/its lack of values or experience distress, shame, or so on). Second, trust requires a vulnerability to another party to perform a particular action that considers the well-being of the truster. However, cynicism does not require interpersonal vulnerability as a precondition. One certainly can be cynical without being vulnerable, whereas trust has no meaning in the absence of vulnerability. Third, the definition of trust also suggests that it is oriented toward facilitating cooperation between two or more parties. Our definition of cynicism makes no such contention. Fourth, because trust, in contrast to cynicism, is not commonly conceptualized as an attitude, an affective component on the part of the belief holder generally is not included within the definition of trust. Organizational cynicism, unlike trust, involves disappointment and frustration, and perhaps even disgust and shame. There is an intensely emotional aspect to cynicism that is lacking in trust. Finally, Wrightsman's (1974) empirical work demonstrates that cynicism and 


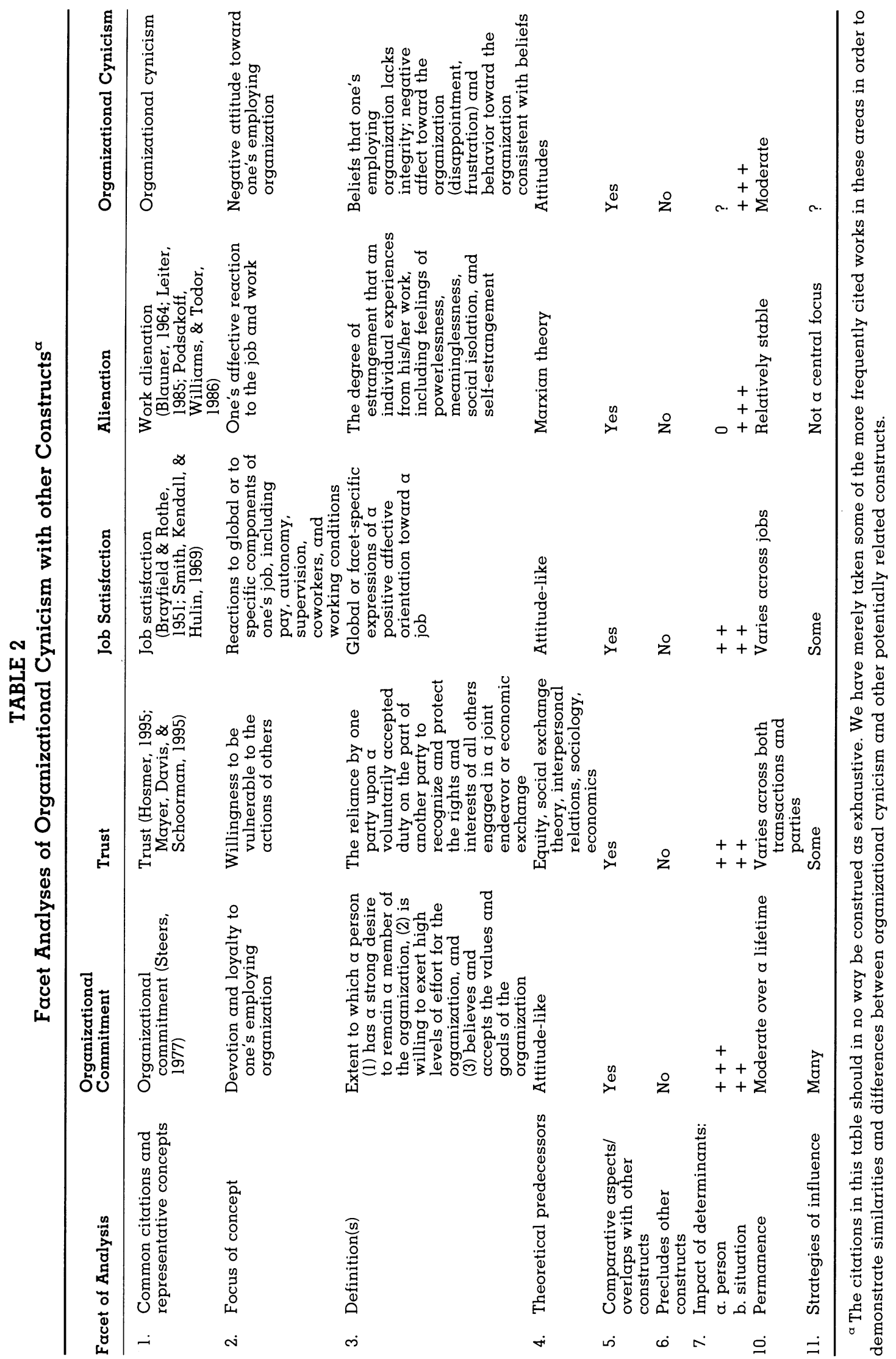


trust are only weakly related, sharing 10 percent common variance.

Alienation. Extending Blauner's (1964) conceptualization of work alienation, Leiter (1985) suggests that alienation includes four facets: (1) powerlessness, (2) meaninglessness, (3) social isolation, and (4) self-estrangement. Management researchers (Organ \& Greene, 1981; Podsakoff, Williams, \& Todor, 1986) have tied alienation to other organizational constructs, such as formalization, role conflict and ambiguity, and organizational commitment. Work alienation is people's reactions to perceiving themselves as not a part of the social or work environment because of the nature of their job. Organizational cynicism, however, while possibly including some overlapping feelings, such as frustration, tension, or anxiety, includes completely different types of beliefs and behaviors. Work alienation does comprise some of the behavioral tendencies we suggest are part of organizational cynicism. However, since alienation is more of a reaction to one's job than the organization (Blauner, 1964; Leiter, 1985), its target is distinct from that of organizational cynicism.

Job satisfaction. This is yet another construct having much prominence in organizational studies. Job satisfaction has been treated as a global concept (Brayfield \& Rothe, 1951) or as a general orientation to a job (Smith, Kendall, \& Hulin, 1969), but also as a more specific construct relating to aspects of jobs, such as pay and supervision (Cook, Hepworth, Wall, \& Warr, 1981). Because of this concept's focus on the job per se as opposed to one's employing organization, we recognize organizational cynicism as distinct from job satisfaction.

\section{DISCUSSION AND CONCLUSION}

We have attempted, in this article, to address the question of conceptualizing organizational cynicism. We have answered this question by defining organizational cynicism as a negative attitude toward the organization, comprising certain types of belief, affect, and behavioral tendencies. This conceptualization sets the stage for a considerable research agenda on organizational cynicism. One major step will be to operationalize our conception of organizational cynicism using the tripartite structure that we have imported from attitude theory.

A second major step will be to begintheoretically and empirically-to grapple with the causes of cynicism in organizations. Researchers potentially could employ a variety of models to predict why some people are so much more cynical about their organizations than others. For example, organizational cynicism could be understood as a result of processes involving leadership, power distribution, organizational change, or procedural justice.

A third step will be to determine the effects of organizational cynicism. Outcomes of cynicism could include such constructs as organizational commitment, organizational citizenship, and participation in team-based activities, such as employee involvement and process improvement. Although we have speculated to some degree about cynicism's effects on the organization, empirical work will be needed to answer this question with any confidence.

In conclusion, organizational cynicism presents a new and challenging research opportunity, which builds on but also goes beyond existing constructs and theoretical frameworks. Research on cynicism should help us to better understand a phenomenon that is pervasive in modern organizations, and perhaps to find better ways to manage or prevent it.

\section{REFERENCES}

Ajzen, I. 1994. Attitudes. In R. J. Corsini (Ed.), Encyclopedia of psychology (2nd ed.): 114-116. New York: Wiley.

Aktouf, O. 1992. Management and theories of the 1990's: Toward an initial radical humanism? Academy of Management Review, 17: 407-431.

Allport, G. W. 1935. Attitudes. In C. Murchison (Ed.), Handbook of Social Psychology: 798-844. Worcester, MA: Clark University Press.

Andersson, L. 1996. Employee cynicism: An examination using a contract violation framework. Human Relations, 49: 1395-1418.

Andersson, L., \& Bateman, T. S. 1997. Cynicism in the workplace: Some causes and effects. Journal of Organizational Behavior, 18: 449-470.

Barefoot, J. C., Dodge, K. A., Peterson, B. L., Dahlstrom, W. G., \& Williams, R. B. 1989. The Cook-Medley hostility scale: Item content and ability to predict survival. Psychosomatic Medicine, 51: 46-57.

Bateman, T. S., Sakano, T., \& Fujita, M. 1992. Roger, me, and my attitude: Film propaganda and cynicism toward corporate leadership. Journal of Applied Psychology, 77: 768-771.

Becker, T. E. 1998. Integrity in organizations: Beyond honesty and conscientiousness, Academy of Management Review, 4l: 154-161. 
Blauner, R. 1964. Alienation and freedom: The factory worker and his industry. Chicago: University of Chicago Press.

Brayfield, A. H., \& Rothe, H. F. 1951. An index of job satisfaction. Journal of Applied Psychology, 33: 307-311.

Breckler, S. J. 1984. Empirical validation of affect, behavior, and cognition as distinct components of attitude. Journal of Personality and Social Psychology, 47: 1191-1205.

Bromiley, P. B., \& Cummings, L. L. 1995. Transactions costs in organizations with trust. Research on Negotiation in Organizations, 5: 219-247.

Cook, J. D., Hepworth, H. J., Wall, T. D., \& Warr, P. B. 1981. The experience of work. New York: Academic Press.

Cook, W. W., \& Medley, D. M. 1954. Proposed hostility and parasaic virtue scales for the MMPI. Journal of Applied Psychology, 38: 414-418.

Costa, P. T., Zonderman, A. B., McCrae, R. R., \& Williams, R. B. 1986. Cynicism and paranoid alienation in the Cook and Medley HO scale. Psychosomatic Medicine, 48: 283-285.

Cunniff, J. 1993. If only the bosses would get out of the way. Marketing News, 27(4): 4-5.

Dutton, J. E., Dukerich, J. M., \& Harquail, C. V. 1994. Organizational images and member identification. Administrative Science Quarterly, 39: 239-263.

Eagly, A. H., \& Chaiken, S. 1993. The psychology of attitudes. Fort Worth, TX: Harcourt Brace Jovanovich.

Fuller, B. A. G. 1931. History of Greek philosophy. New York: Henry Holt.

Goldner, F. H., Ritti, R. R., \& Ference, T. P. 1977. The production of cynical knowledge in organizations. American Sociological Review, 42: 539-551.

Graham, J. R. 1993. MMPI-2: Assessing personality and psychopathology (2nd ed.). New York: Oxford University Press.

Greenglass, E. R., \& Julkunen, J. 1989. Construct validity and sex difference in Cook-Medley hostility. Personality and Individual Differences, 10: 209-218.

Greilsamer, M. 1995. The Dilbert barometer. Across the Board, March: 39-41.

Guttman, L. 1954. An outline of some new methodology in social research. Public Opinion Quarterly, 18: 395-404.

Hart, P. M. 1997. Personality, work-related experiences and organizational cynicism: $A$ longitudinal study. Paper presented at the Society for Industrial and Organizational Psychology Annual Meeting, St. Louis, MO.

Hilgard, E. R. 1980. The trilogy of mind: Cognition, affection, and conation. Journal of the History of the Behavioral Sciences, 16: 107-117.

Hosmer, L. T. 1995. Trust: The connecting link between organizational theory and philosophical ethics. Academy of Management Review, 20: 379-403.

Izard, C. E. 1977. Human emotions. New York: Plenum.

Jones, E. E., \& Davis, K. E. 1965. From acts to dispositions: The attribution process in person perception. In L. Berkowitz (Ed.), Advances in experimental social psychology, vol 2. New York: Academic Press.
Kanter, D. L., \& Mirvis, P. H. 1989. The cynical Americans. San Francisco: Jossey-Bass.

Kouzes, J. M., \& Posner, B. Z. 1993. Credibility. San Francisco: Jossey-Bass.

Leiter, J. 1985. Work alienation in the textile industry: Reassessing Blauner. Work and Occupations, 12: 479-498.

Levinson, H. 1965. Reciprocation: The relationship between man and organization. Administrative Science Quarterly, 9: 370-390.

Mack, B. L. 1993. The lost gospel: The book of $Q$ and Christian origins. New York: Harper Collins.

Mayer, R. C., Davis, J. H., \& Schoorman, F. D. 1995. An integrative model of organizational trust. Academy of Management Review, 20: 709-734.

More, P. E. 1923. Hellenistic philosophies. Princeton, NJ: Princeton University Press.

Morrow, P. C. 1983. Concept redundancy in organizational research: The case of work commitment. Academy of Management Review, 8: 486-500.

Neiderhoffer, A. 1967. Behind the shield. Garden City, NJ: Doubleday.

Northrop, F. S. C. 1959. The logic of modern physics. New York: Macmillan.

O'Connell, B. J., Holzman, H. H., \& Armandi, B. R. 1986. Police cynicism and the modes of adaptation. Journal of Police Science and Administration, 14: 307-313.

Organ, D. W., \& Greene, C. N. 1981. The effects of formalization on professional involvement: A compensatory process approach. Administrative Science Quarterly, 26: 237-252.

Pfeffer, J. 1981. Management as symbolic action: The creation and maintenance of organizational paradigms. Research in Organizational Behavior, 3: 1-52.

Podsakoff, P. M., Williams, L. J., \& Todor, W. D. 1986. Effects of organizational formalization on alienation among professionals and nonprofessionals. Academy of Management Journal, 29: 820-831.

Porter, L. W., Steers, R. M., Mowday, R. T., \& Boulian, P. V. 1974. Organizational commitment, job satisfaction, and turnover among psychiatric technicians. Journal of Applied Psychology, 59: 465-476.

Reichers, A. E., Wanous, J. P., \& Austin, J. T. 1997. Understanding and managing cynicism about organizational change. Academy of Management Executive, 11(1): 4859.

Schwab, D. P. 1980. Construct validity in organizational behavior. In B. M. Staw and L. L. Cummings (Eds.), Research in organizational behavior, vol. 2: 3-43. Greenwich, CT: JAI Press.

Shapira, Z., \& Zevulun, E. 1979. On the use of facet analysis in organizational behavior research: Some conceptual considerations and an example. Organizational Behavior and Human Performance, 23: 41 1-428.

Shapiro, E. C. 1996. The "glow and tingle" audit. The Wall Street Journal, January 26. 
Smith, M. B. 1947. The personal setting of public opinions: A study of attitudes toward Russia. Public Opinion Quarterly, 11: 507-523.

Smith, P. C., Kendall, L. M., \& Hulin, C. L. 1969. The measurement of satisfaction in work and retirement. Chicago: Rand McNally.

Steers, R. M. 1977. Antecedents and outcomes of organizational commitment. Administrative Science Quarterly, 22: $46-56$.

Vance, R. J., Brooks, S. M., \& Tesluk, P. E. 1996. Organizational cynicism and change. Working paper, Pennsylvania State University, University Park.
Vroom, V. H. 1964. Work and motivation. New York: Wiley.

Wanous, J. P., Reichers, A. E., \& Austin, J. T. 1994. Organizational cynicism: An initial study. Academy of Management Best Papers Proceedings: 269-273.

Weick, K. 1979. The social psychology of organizing. Reading, MA: Addison-Wesley.

White, S. E., \& Mitchell, T. R. 1976. Organizational development: A review of research content and research design. Academy of Management Review, 1: 57-73.

Wrightsman, L. S. 1974. Assumptions about human nature: $\bar{A}$ social-psychological analysis. Monterey, CA: Brooks/ Cole.

James W. Dean, Jr., received his Ph.D. from Carnegie-Mellon University. He is an associate professor of management at the Kenan-Flagler Business School, University of North Carolina at Chapel Hill. His current research interests include organizational change, performance improvement, and aesthetic aspects of organizations.

Pamela Brandes is an assistant professor of management at Southern Connecticut State University. Her research interests include employee-organization linkages and strategic human resource management.

Ravi Dharwadkar received his Ph.D. from the University of Cincinnati. He is a visiting assistant professor of management at the University of Cincinnati. His research interests include international management issues in emerging markets and employee attitudes. 